\title{
Conformation of the Group II Intron Branch Site in Solution
}

Jörg C. Schlatterer, Samuel H. Crayton, and Nancy L. Greenbaum

Department of Chemistry and Biochemistry, Florida State University, 214 DLC, Tallahassee, Florida 32306-4390

\section{Experimental procedure}

\section{Fluorescence spectroscopy}

RNA strands with 2-aminopurine were purchased from Dharmacon and deprotected by their recommended procedure. The dried pellets were dissolved in sodium phosphate buffer $(10 \mathrm{mM}$ sodium phosphate, $0.1 \mathrm{mM}$ EDTA, $\mathrm{pH}$ 6.4). Oligomers $(3 \mu \mathrm{M})$ were then folded by heating to $90^{\circ} \mathrm{C}$ for three minutes and cooling down slowly to $25^{\circ} \mathrm{C}$ before chilling on ice. The samples were dried and dissolved in an aqueous $\mathrm{NaCl}$ solution. The final concentration was $3 \mu \mathrm{M}$ RNA, $10 \mathrm{mM}$ sodium phosphate, $0.1 \mathrm{mM}$ EDTA, $100 \mathrm{mM}$ sodium chloride, $\mathrm{pH}$ 6.4. Presence of a single fold was verified by nondenaturing PAGE, and the hairpin structure was identified via NOE cross peaks of the tetraloop ${ }^{1}$. Magnesium titration followed as indicated.

Experiments were performed at a Cary Eclipse (Varian) fluorescence spectrometer. The quartz cuvettes (Starna Cells, 4mm square) contained $130 \mu$ l buffered RNA solution. Excitation occurred at $306 \mathrm{~nm}$ and $25^{\circ} \mathrm{C}$. All scans were performed three times and averaged.

\section{NMR spectroscopy}

The 33-nt D6 sequence and D6 del were purchased from Dharmacon and deprotected via standard procedure. 37-nt oligonucleotides (sequence in Figure 2) were synthesized by in vitro transcription with T7 RNA Polymerase from a double stranded, synthetic DNA template containing a 17 nucleotide double stranded promoter region ${ }^{2}$. In comparison, to the original Domain 6 , we extended the hairpin by two additional G-C base pairs (G1, G2, C36, C37) to stabilize the helix terminus and to improve the yield of the in vitro transcription. Transcription buffer contained $40 \mathrm{mM}$ Tris ( $\mathrm{pH} 8.3$ ), $0.01 \%$ Triton X-100, $1 \mathrm{mM}$ spermidine, and $30 \mathrm{mM}$ DTT. T7 RNA polymerase was isolated from 
overexpressing strain of E. coli essentially according to the method of Wyatt et al. (1991). The optimization of the transcription conditions was carried out in small reactions, using varied concentrations of NTPs (SIGMA), ${ }^{15}$ N-labelled GTP and UTP (Silantes), DNA template (IDT), T7 RNA polymerase, $\mathrm{MgCl}_{2}$ (SIGMA) and GMP (SIGMA). Final condition for the large-scale transcription was $0.2 \mu \mathrm{M}$ DNA template, $1 \mathrm{mM}$ total NTPs, $10 \mathrm{mM} \mathrm{MgCl} 2$. Transcription reactions of $20 \mathrm{ml}$ were carried out at $37^{\circ} \mathrm{C}$. The RNA product was purified on denaturating $15 \%$ polyacrylamide gels (w/v), UV-shadowed and excised from the gel. RNA was recovered by the crush and soak method with $0.3 \mathrm{M}$ sodium acetate ( $\mathrm{pH}$ 5.5) and ethanol precipitation.

RNA pellets were dissolved in high salt buffer $(10 \mathrm{mM}$ sodium phosphate, $10 \mathrm{mM}$ EDTA, $1 \mathrm{M}$ sodium chloride, $\mathrm{pH}$ 6.4) and then exchanged into NMR buffer $(10 \mathrm{mM}$ sodium phosphate, $0.1 \mathrm{mM}$ EDTA, $100 \mathrm{mM}$ sodium chloride, $\mathrm{pH}$ 6.4). The RNAs were then folded by heating to $90^{\circ} \mathrm{C}$ for three minutes and cooling down slowly to $37^{\circ} \mathrm{C}$ before chilling on ice. After folding, the samples were suspended in $90 \% \mathrm{H}_{2} \mathrm{O} / 10 \% \mathrm{D}_{2} \mathrm{O}(\mathrm{v} / \mathrm{v})$. Final concentration of the RNA in the NMR samples was $\approx 0.85 \mathrm{mM}$. Microvolume NMR tubes (Shigemi) were used for all NMR data collection.

All NMR data were acquired on a 600MHz Varian Unity Plus spectrometer (National High Magnetic Field Laboratory, Tallahassee, Florida) or $500 \mathrm{MHz}$ Varian Inova500 spectrometer (Department of Chemistry and Biochemistry, Florida State University, Tallahassee, Florida). Exchangeable protons were observed at $4{ }^{\circ} \mathrm{C}$ with samples in aqueous buffer including $10 \% \mathrm{D}_{2} \mathrm{O}$ to obtain lock. The jumpreturn echo pulse sequence ${ }^{3}$ was used for water suppression. NOESY spectra were collected at 80 , 150, and $300 \mathrm{~ms}$ mixing times and different magnesium concentrations. Definitive identification of the G-U base pairs followed by ${ }^{1} \mathrm{H},{ }^{15} \mathrm{~N}$ HSQC spectra of $37 \mathrm{nt}$-RNA (just Gs and Us were ${ }^{15} \mathrm{~N}$-labeled) in $90 \% \mathrm{H}_{2} \mathrm{O} / 10 \% \mathrm{D}_{2} \mathrm{O}\left(4^{\circ} \mathrm{C}\right)$. Nonexchangeable resonances were assigned by reference to $2 \mathrm{D}{ }^{1} \mathrm{H},{ }^{1} \mathrm{H}$ NOESY spectra (80-, 150-, 300-ms mixing times) and ${ }^{1} \mathrm{H},{ }^{1} \mathrm{H}-\mathrm{TOCSY}$ (80- and 40-ms mixing times) spectra of RNA in $\mathrm{D}_{2} \mathrm{O}$ at $28^{\circ} \mathrm{C}$. NMR data were processed using Varian VNMR software. 
(1) Jucker, F. M.; Heus, H. A.; Yip, P. F.; Moors, E. H.; Pardi, A. J. Mol. Biol. 1996, 264, 968-980.

(2) Milligan, M. J.; Groebe, D. R.; Witherell, G. W.; Uhlenbeck, O. C. Nucleic Acids Research 1987, 15, 8783-8798.

(3) Sklenar, V.; Bax, A. J. Magn. Reson. 1987, 74, 469-479.
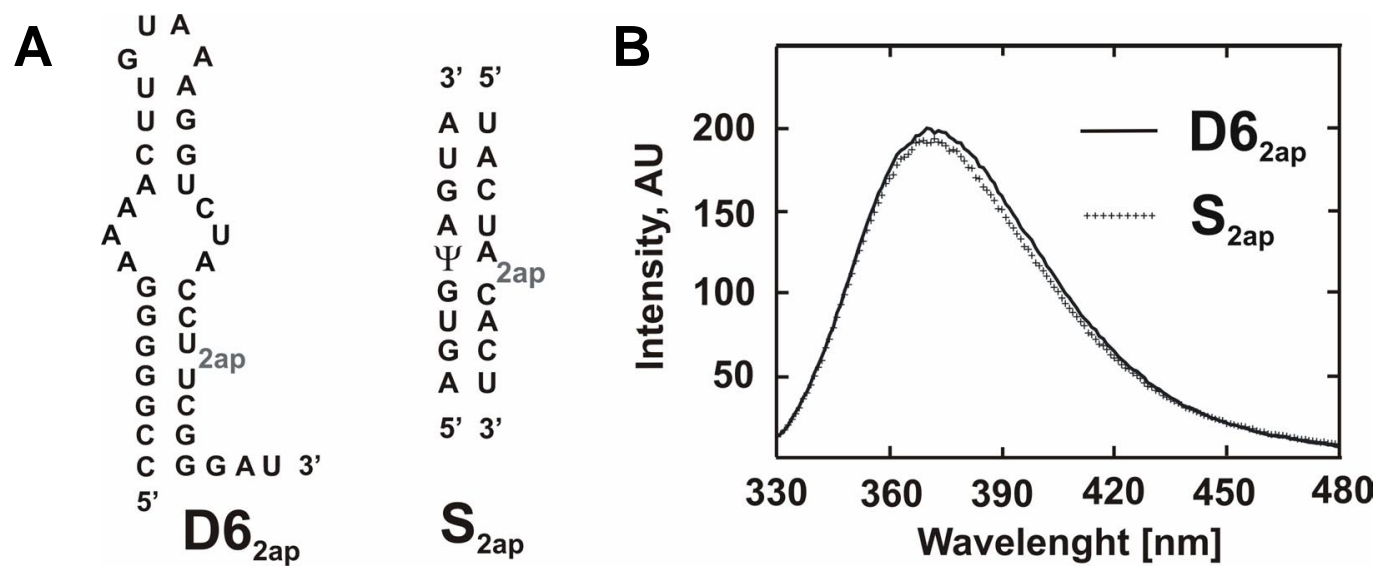

\section{Figure S1.}

(A) Constructs for fluorescence assay: full length D6 (D6 $\left.6_{2 a p}\right)$, spliceosomal branch site duplex $\left(\mathrm{S}_{2 \mathrm{ap}}\right)$. The branch site adenine is substituted against a 2-aminopurine (2ap). (B) Fluorescence spectra of $\mathrm{D6}_{2 \text { ap }}$ and $\mathrm{S}_{2 \mathrm{ap}}$. See text for experimental detail. 


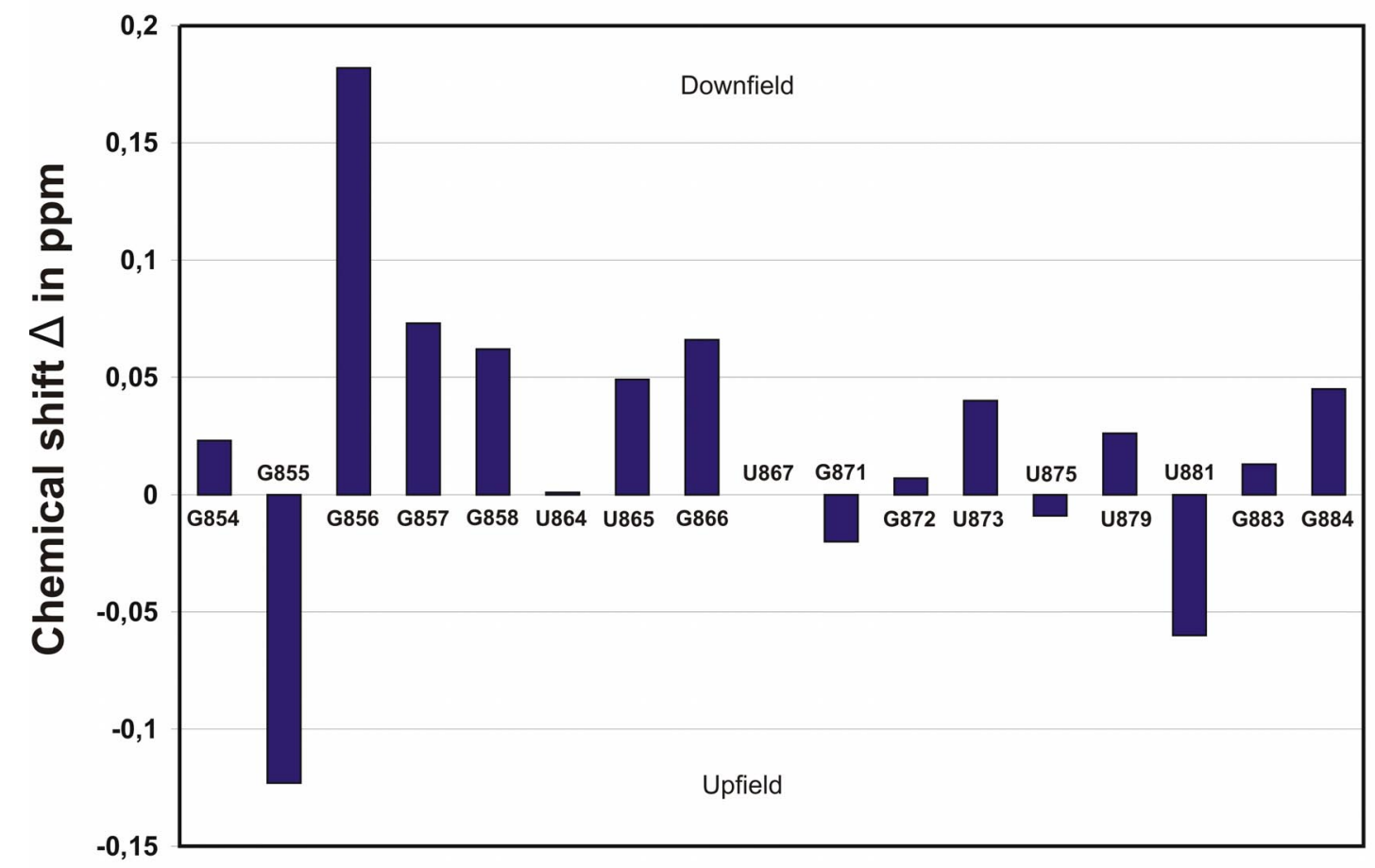

Figure S2.

Change in chemical shifts of imino protons in presence of $5 \mathrm{mM} \mathrm{Mg}^{2+}$ is depicted. Conditions were those described above and in the legend of figure 2 .

Figure S3:

Numbering scheme for $\mathrm{D6}_{2 \mathrm{ap}, \mathrm{del}}$

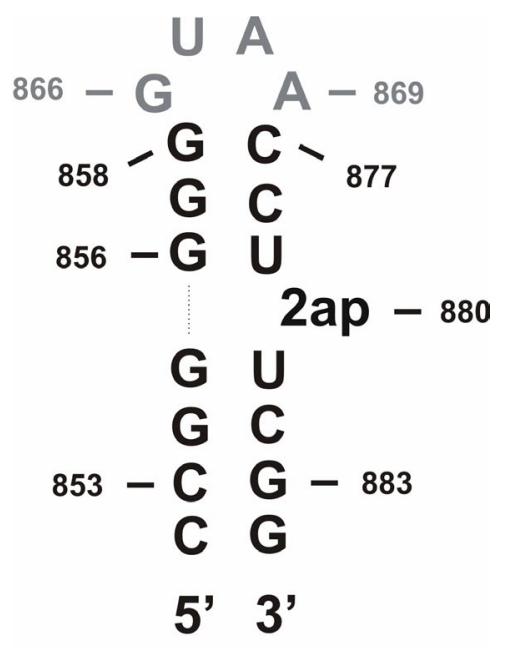

D6 $6_{\text {2ap,del }}$ 


\section{Figure S4:}

2-aminopurine as a structural probe for the branch site adenosine shown by 1H-NOESY spectra for D6 $_{\text {del }}$ (left) and D6 2 ap,del (right) acquired in presence of $5 \mathrm{mM} \mathrm{Mg(II)}$ at $277 \mathrm{~K}$ and $300 \mathrm{~ms}$ mixing time.

In comparison, both NMR spectra indicate similar resonances for the according imino protons in both constructs; the findings for the full D6 constructs were analogous (data not shown). Thus the 2aminopurine substitution for the branch site adenosine does not influence the overall structure of D6.

D6 $6_{\text {del }}$

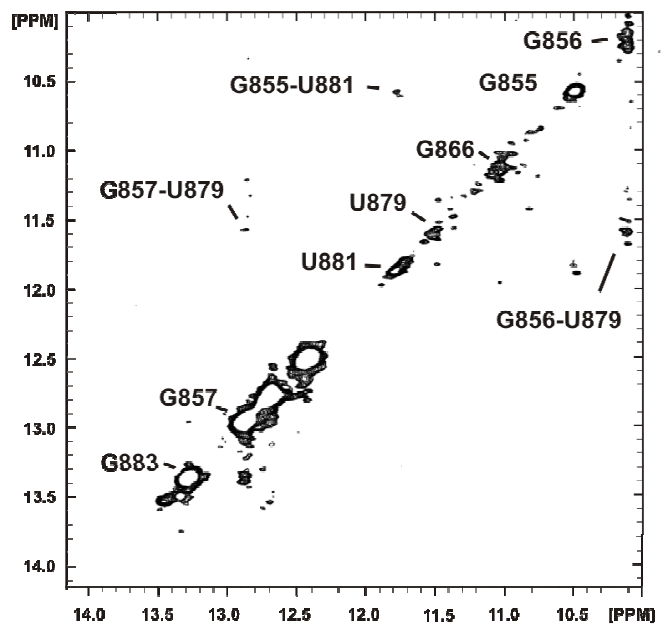

D6 $6_{\text {2ap,del }}$

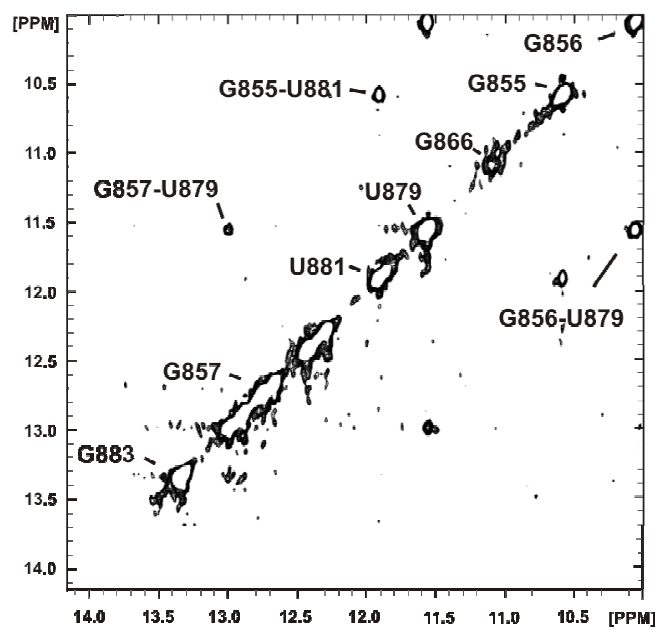

